\title{
QUARANTINE AND THE LAW: THE 2003 SARS EXPERIENCE IN CANADA (A New Disease Calls on Old Public Health Tools)
}

\author{
NOLA M. RIES'
}

The authority to quarantine individuals was lested by the 2003 global outbreak of SARS. Quaranine was used during that time as a public health intervemion cool to attempt to control the disease in Toronto. The outbreak put the public health preparedness of the Ontario legal system to the test. This article examines the legal issues related to the use of quarantine as a tool to control infectious disease outbreaks using the Ontario SARS epidemic as a case study.

The author first analyzes the laws authorizing public health officials to use quarantine and then identifies the legislative gaps that SARS exposed in these laws. The article shen looks at the curren legislative reform efforts so create a more prepared legal environment in the event of another public heallh crisis such as SARS. In addition, the impact of quarantine on an individual and his or her family, including social and economic impacts, as well as its effect on the health care system is discussed. Finally, the legal limis on the use of quarantine are further examined.

The author concludes that. because it is likely that a novel infectious agent such as SARS will surface in the furure. the public health authorities must be vigilam by ensuring public health legal preparedness.
$L$ awlorité de meltre des personnes en quarantaine a été testée lors de l'épidémie de SRAS en 2003. La mise en quarantaine a été utilisée en tant qu'outil d'intenention de santé publique dans le buf d'essayer de controler la maladie da Toronto. L 'épidémie a mis à l'epreuve le degré de préparation en santé publique du systeme juridique de l'Ontario. $L$ article porte sur les questions juridiques relatives à la mise en quaramaine en tan qu'outil de controle d'epidémies de maladies infectieuses usilisant I'ejpidémie de SRAS de l'Ontario en sant qu'étude de cas.

$L$ auteur commence par analyser les lois autorisant les representanis de la santé publigue da avoir recours à la mise en quarantaine, puis détermine les lacunes de ces lois que le SRAS a fait ressortir. Larlicle se penche enswite sur l'effort de reforme legislative actuel visant à créer un milieu juridique mieux préparé dans le cas d'une autre crise de santé publique comme celle du SRAS. En outre. I'impact de la mise en quaranlaine sur une personne et sa famille. y compris les effets sociaux ef économiques en plus des effels sur le systeme de santé publique. y est discule. Enfin, les limiles ligales sur le recours à la mise en quarantaine y sont examinécs.

$L$ anteur conclut que. comme un nowvel agent infectieux comme le SRAS surgira sans doute à lavenir. les autorités en matière de sunté publique doivent ètre vigilantes en s'assurant que le système juridique de la santé publique esi preit.

\section{TABLE OF CONTENTS}

I. INTROdUCTION ............................... 530

II. SARS IN CANADA: A BRIIF CHRONOI.OGY $\ldots \ldots \ldots \ldots \ldots \ldots \ldots 531$

III. A BRIEF HISTORY OF QUARANTINE $\ldots \ldots \ldots \ldots \ldots \ldots \ldots \ldots \ldots, 532$

IV. LEGISLATIVE AUTHORITY FOR

Quarantine in Canada ....................... 533

A. Federal Quarantine Powers $\ldots \ldots \ldots \ldots \ldots \ldots \ldots \ldots, 533$

B. Provincial Quarantine Authority $\ldots \ldots \ldots \ldots \ldots \ldots \ldots 535$

Nola M. Ries. M.P.A.. LL.M.. is a Research Associate with the lleallh Law lustitute. I/niversity of Alberna. The author acknowledges finding support from the Canndian Institutes of I lealth Restint ch and is grateful to Geofr Moysa for his able research assistance. This article is based, in part, on a paper presented at "Ethics and Epidemics: An International Conference on the I:thical I)ımensions of Epidemic Control," held in Albany \& Schnectady. New York in March 2004. That paptr will appecar as a chapter in Advances in Bioethics [in press]. edited by $W$. Shelton et at. The authot has recieivid permission from Elsevier to reproduce significant portions of that chapter in this article 
V. Legislative Gaps and Operational Deficiencies $\ldots \ldots \ldots \ldots \ldots \ldots 57$

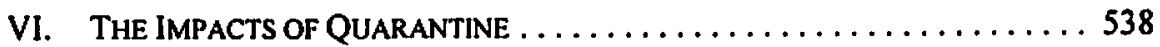

VII. LEgal ChaLlenges To Quarantine ORdERS $\ldots \ldots \ldots \ldots \ldots \ldots \ldots 541$

VIII. CONCLUSION $\ldots \ldots \ldots \ldots \ldots \ldots \ldots \ldots \ldots \ldots \ldots \ldots \ldots$

It is not surprising that the advent of a frightening, seemingly new public health menace has prompted consideration of coercive measures. Throughout history, new plagues have been met with restrictions upon individual liberties.'

\section{INTRODUCTION}

It is now trite to say that the 2003 emergence and outbreak of severe acute respiratory syndrome (SARS) was a wake-up call for the need to reform public health systems at all levels - locally, nationally and internationally - to ensure preparedness for the next crisis. The requirement for public health reform encompasses a need to review and revise laws to ensure public health officials have appropriate legal authority to support their actions. It also requires critical assessment of such actions to ensure they do not unduly abrogate individual rights and freedoms. The concept of "public health legal preparedness" has been described as "a subset of public health preparedness and can be defined as attainment by a public health system of legal benchmarks essential to the preparedness of the public health system."2

Although the SARS outbreak was relatively short-lived, ${ }^{3}$ it instigated a review of various federal and provincial laws relevant to public health preparedness. In this article, I examine legal issues related to the use of quarantine as a tool to control infectious disease outbreaks. ${ }^{4}$ Using the Canadian experience with SARS as a case example, I discuss federal and provincial laws that authorize public health officials to use quarantine, identify legislative gaps that SARS exposed and highlight current legislative reform efforts. In addition, I comment on quarantine's impact on individuals, including psychological and economic impacts, as well as its effect on the health care system. Finally, I examine legal limits on the use of quarantine.

1 Wendy E. Parmet, "Quarantine Redux: Bioterrorism, AIDS and the Curtailment of Individual Liberty in the Name of Public Health" (2003) 13 Health Matrix 85 at 95.

1 Anthony D. Moulton, el al., "What is Public Health Legal Preparedness?" (2003) 3I J.L. Med. \& Ethics 672 at 674 .

Compared with the HIV/AIDS pandemic that emerged in the early 1980s and remains a global public health scourge, the speed with which the SARS outbreak was contained is remarkable. For commentary on the disparities between the responses to HIV and SARS, sec e.g. Lawrence K. Altman, "The Doctor's World: Lessons of AJDS, Applied to SARS" The New York Times (6 May 2003) FI.

- In this aricle, I use the term "quarantine" to refer to restricting the physical liberty of a person who is stispected of having been exposed to a communicable disease. In contrast, "isolation" refers to the segregation of a person known to be infected. 


\section{SARS in Canada: A Brief Chronology}

SARS emerged in China in November 2002. The disease travelled to Canada in late February 2003 when an elderly woman who acquired the disease in Hong Kong returned to her home in Toronto. She died ten days after her return. Two days later, her 44-year-old son went to the emergency department of a major Toronto hospital exhibiting high fever, a severe cough and difficulty breathing - symptoms that a couple of weeks later would trigger alarm bells as a potential SARS case but, at the time, health care workers did not know what confronted them. While awaiting admission, the man remained in an open area of a busy emergency department for 18 to 20 hours. This delay in admitting and isolating him was due, in part, to hospital overcrowding. Many patients and staff were exposed to the man before he was isolated. This patient died a week later. By then, public health officials realized that the mysterious disease outbreak in Asia had gained a foothold in Canada.

SARS began to spread to patients, health care workers and visitors in several hospitals in the Toronto area. Hospitals at the epicentre of the outbreak began closing emergency and intensive care services and refused new admissions. By late March 2003, the Ontario government amended its public health statute, the Health Protection and Promotion Act, ${ }^{6}$ to classify SARS as a reportable, communicable disease. With the addition of SARS to the statute, public health officials could trace infected individuals and their contacts and use measures, including quarantine, to try to limit spread of the disease.

Quarantine was used extensively during the outbreak, with tens of thousands of individuals observing quarantine. For example, anyone who had visited certain hospitals during specific time periods was asked to observe quarantine. 1,700 high school students were quarantined after one student at the school became ill. In most cases, individuals complied with quarantine on a voluntary basis, but public health officials sought legally enforceable quarantine orders in a small number of cases. Tomislav Svoboda and colleagues note that over 13,000 Toronto residents voluntarily complied with quarantine and the city's public health department had to resort to mandatory orders in only 27 cases. ${ }^{7}$ This accounted for just 0.1 percent of individuals requiring quarantine. ${ }^{8}$

This contrasts with other countries where quarantine was enforced more oppressively. In China, individuals were threatened with imprisonment or execution;" in Hong Kong, authorities used barricades and tape to attempt to quarantine residents of a large housing

5 For a comprehensive discussion of the SARS outbreak in Canada, see Canada. National Advisory Committee on SARS and Public Health, Learning from SARS: Renewal of Public Hecalth in Canada (Ottawa: Health Canada, 2003) (Commissioner: David Naylor), online: <www phac-aspe.ge.ca/ publicat/sars-sras/naylor/> ["Naylor Report"]. The chronology in this section is based on the Naylor Report.

"R.S.O. 1990, c. H-7.

1 Tomislav Svoboda, et al., "Public Health Measures to Control the Spread of the Severe Acute Respiratory Syndrome during the Outbreak in Toronto" (2004) 350 New Fngland Journal of Medicine 2352.

* Ibid. These numbers do not take into account persons outside the inetropolitan region served by the Toronto Public Health department.

" Mike Mitka, "SARS Thrusts Quarantine into the Limelight" (2003) 290 JAMA 1696. 
complex; ${ }^{10}$ and in Singapore, officials used surveillance cameras and electronic monitoring devices to track those who were supposed to observe quarantine."

Many health care workers in the Toronto region were quarantined. "Work quarantine" was also imposed, which required health workers to travel directly between work and home without using public transit and without stopping at any other destination. They also had to separate themselves from family members while at home, wear masks when in contact with others in their household, and not have visitors. Over half of Toronto's 850 paramedics ended up under ten-day home quarantine during the outbreak. ${ }^{12}$

In total, Canada had 438 cases of SARS; 251 of those were probable and 187 suspected. Ultimately, 44 people died from the disease.

\section{A Brief History of Qilarantine}

Quarantine is one of the oldest public health tools, used by authorities to quell the spread of disease long before microscopic agents were understood as the source of contagion. ${ }^{3}$ Its roots are in the quarantine of shipping vessels, primarily to prevent spread of contagion via infested cargo and persons. One commentator notes that "[q]uarantine practices had long been notorious for their ill-treatment of and cruelty to travelers. For centuries, travelers faced involuntary isolation based on arbitrary regulations and irrational fears in often unhealthy, degrading conditions, sometimes reinforced by the threat of execution."

Indeed, quarantine has a history of being imposed with a heavy hand by officials motivated by fear and prejudice rather than medical fact. In 1900, after a bubonic plague victim was found in San Francisco's Chinatown, the U.S. President ordered quarantine of all Chinese and Japanese residents of the city based, in part, on "the notion that Asians were particularly susceptible to plague because of their dietary reliance on rice rather than animal protein."1s

Further evidence of questionable attitudes toward, and uses of, quarantine emerged in the earlier years of the HIV pandemic. American public opinion polls in the 1980 s revealed that " 28 to 54 percent of the respondents favored 'quarantine' of people with AIDS in 'special

Apoorva Mandavilli, "SARS epidemic unmasks age-old quarantine conundrum" (2003) 9 Nature Medicine 487. For details of the Hong Kong government report into the outbreak and spread of SARS in this building complex, see Hong Kong Department of Health, "Outbreak of Severe Acute Respiratory Syndrome (SARS) at Amoy Gardens, Kowloon Bay, Hong Kong: Main Findings of the Investigation" (2003). online: <www.info.gov.hk/info/ap/pdf/amoy_c.pdP.

Mandavilli, ibid.

Alexis Silverman. Andrew Simor \& Mona R. Loutfy. "Toronto Emergency Medical Services and SARS" Letter to the Editor (2004) 10 Emerging Infecticus Diseases 1688.

" Paul S. Sedhev, "The Origin of Quarantine" (2002) 35 Clinical Infectious Diseases 1071:1:G. Clemow, "The Origin of 'Quarantine"” (1929) I British Medical Journal 122.

1t David P. Fidler, Imernational Law and Public Ilealh: Materials on and Analysis of Global Health Jurisprudence (Ardsley, N.Y.: Transnational Publishers, 2000) at 289.

1" Paul J. Edelson, "Quarantine and Social Inequity" (2003) 290 JAMA 2874 at 2874 . This presidential order was subsequently overturned following a constitutional challenge. 
places to keep them away from the general public." 16 The nation of Cuba did, in fact. institute mandatory quarantine for HIV-positive persons between 1986 and 1994. ${ }^{17}$

While there is no evidence that Canadian public health officials imposed quarantine in a discriminatory manner during the 2003 SARS outbreak, ${ }^{18}$ it is important to recall historical lessons to ensure past harms are not perpetuated.

\section{Legislative. Aitmority foh Quarantine in Canada}

The Canadian Constitution divides authority over various subjects between the federal and provincial governments. ${ }^{19}$ The provinces have primary authority over health care though the federal government exercises some authority in the health sphere through, inter alia, its spending powers, criminal law power, and "peace, order and good government power," which authorizes the federal government to act during times of national emergency. ${ }^{20}$ The federal government also has explicit constitutional authority to quarantine persons and conveyances (such as airplanes and shipping vessels) entering and leaving the country. ${ }^{21}$ While provincial governments have authority to impose quarantine within provincial borders the federal government's quarantine powers are concerned with the international movement of people and goods. Both federal and provincial quarantine powers came into play during the 2003 SARS outbreak.

\section{A. Fedrral Quarantine. Powers}

The federal Quarantine $A \mathrm{Ct}^{22}$ and regulations ${ }^{23}$ authorize the Government of Canada to appoint quarantine officers who may detain and assess individuals entering and leaving the country who are suspected of having a contagious disease listed in the regulations (cholera,

Larry Gostin \& Andrew Ziegler. " $\wedge$ Review of AIDS-Related Legislative and Regulatory Policy in the United States" (1987) 15 I. Med. \& I leath Care 5 at II

$17 \quad H$. Hansen \& N. Groce. "Human Immunodeliciency Virus and Quarantine in Cuba" (2003) 290 JAMA 2875. The authors note that Cuba reports a very low HIV infection rate but "[n]o systematic epidemiological studies of HIV inlection in Cuba have been published that would clarify the relative effects of quarantine" and uther measures (at 2875)

In fact, those who were asked to observe guarantine represented a wide cross-section of the population and individuals disadvantaged by poverty. race or disability were not disproportionately represented. One survey of over a hundred Torontonians who were in quarantine revealed that 72 percent lsad a college education or higher and 48 percent had an annual household income of more than $\$ 75,000$. See Laura Hawryluck ef al., "SARS Control and Psychological Effects of Quarantine, Toronto, Canada" (2004) 10:7 Emerging Infectious Discascs 1206. Although the sample size was relatively small, these findings were not surprising considering that health care workers comprised a large number of people who observed quarantine. Constitution Act. 1867 (U.K.), 30 \& 31 Vict., c. 3, reprinted in R.S.C. 1985. App. II. No. 5. ss. 91-92. For further discussion, see Martha Jackman, "Constilutional Jurisdiction Over llealth in Canada" (2000) 8 Health I..I 95

$\therefore$ Supra note 19. Section 91(11) of the Constitution Act. 1867 confers specifie power to the federal government over "Quarantine and the Establishment and Masintenance of Marine Hospitals."

$\because \quad$ R.S.C. 1985, c. Q-1.

"Quarantine Regulations, C.R.C., c. 1368. A new Quaramine Act received Royal Assent on 12 May 2005, but will not come into force until new regulations are prepared. The Public Health Agency ot Canada expects updated regulations by fall 2006. 
plague, smallpox and yellow fever) or any other dangerous disease. ${ }^{24}$ Persons who are quarantined may appeal their detention to the federal Deputy Minister of Health or the Deputy's designate. ${ }^{25}$ Officers may also hold and inspect conveyances suspected of carrying persons or cargo that may be infected.

In June 2003, the Canadian government amended the Quarantine Regulations to add SARS to the list of contagious diseases. The incubation period of SARS was described as 20 days, meaning a quarantine officer could detain a person suspected of having SARS up to that period of time. In its public notices about amendments to the Quarantine $A c t$, the federal government acknowledged that the World Health Organization recommended a quarantine period of ten days and advised that quarantine officers would take that recommendation into account if an order had to be made. At the provincial level in Ontario, individuals were asked to observe a ten-day period of quarantine.

Fortunately, during the outbreak, no federal quarantine officer faced a situation requiring the issuance of a quarantine order against an individual. ${ }^{26}$ At the Vancouver International Airport, federal health officials relied on the Quarantine $\mathrm{ACt}$ to detain an aircraft for decontamination because one passenger had SARS-like symptoms. Thermal scanning devices were deployed at the international airports in Toronto and Vancouver to screen for passengers with high temperature. Of approximately 2.4 million air travellers, 832 were identified as requiring further assessment due to high temperature. None had SARS. ${ }^{27}$ Some have questioned the utility of large-scale thermal scanning. In a thorough review of the epidemiology, transmission and control of SARS, Roy Anderson and colleagues note that "[t]he effectiveness of temperature screening at points of entry and exit as a control measure to limit between-country transmission is uncertain at present." ${ }^{23}$ In a subsequent section, I note other shortcomings related to federal capacity to identify exposed or infected individuals at points of entry.

Before the SARS outbreak occurred, the Canadian government was in the process of reviewing its public health legislation, including the Quarantine Act. The emergence of SARS spurred the government to expedite legislative reform of the quarantine law, which was first enacted in 1872. In May 2004, the federal Minister of Health introduced a modernized statute titled An Act to prevent the introduction and spread of communicable diseases. ${ }^{29}$ This law, which received Royal Assent in May 2005 but is not yet in force, is

See supra note 22, ss. 8 and 11 . A "dangerous disease" is defined as one whose introduction to Canada "would, in the opinion of the quarantine officer concerned. constitute a grave danger to public health in Canada" (s. 2).

" $\quad$ bid., s. 9.

: Canada, Health Canada, Quaranime ACt and Regulatons - SARS Amendment (Ottawa: Healih Canada, 2003), online: <www.hc-sc.gc.cavenglish/protection/warnings/sars/fact_sheet.html>

¿Tupra note 5 at 206.

2* Roy M. Anderson et al,, "Epidemiology, transmission dynamics and control of SARS: the 2002-2003 epidemic" (2004) 359 Philosophical Transactions of the Royal Society of London: B 1091 at 1104. 
aimed at focusing greater emphasis on air travel, the modern mode of global disease spread. ${ }^{30}$ The revised legislation also has a more extensive list of contagious diseases ${ }^{31}$ and empowers the federal government to go so far as to close Canadian entry points to arrivals from a jurisdiction with an infectious disease outbreak. The federal government acknowledges this would be "an extreme measure."

In introducing the revised quarantine legislation in the Canadian Parliament, the Minister of State for Public Health remarked that the Quarantine Act was first drafted at

\begin{abstract}
a time when automobiles and jetliners were the stuff of science fiction. Needless to say, times have changed We live in an age when people move from continent to continent in hours and days rather than weeks or months, often in airplanes and ships whose confined spaces provide a perfect breeding ground for highly communicable diseases to spread. Infectious diseases move like wildfire across the planet today. Diseases do not respect borders, so we know that we will face repeated threats to public health in the future. Among the hard lessons learned from the experience of SARS is the need to strengthen our quarantine legislation to help prevent the introduction and spread of both emerging and re-emerging communicable distases. ${ }^{33}$
\end{abstract}

\title{
B. Provincial Quarantine Authority
}

Each province and territory in Canada has public health legislation that establishes the powers of public health officials to carry out various functions including communicable disease control. This encompasses the authority to issue isolation and quarantine orders. In Ontario, the Health Protection and Promotion Act ${ }^{34}$ empowers a medical health officer to order a person who is, or may be infected with a communicable disease to: "isolate himself or herself and remain in isolation from other persons"; otherwise "conduct himself or herself in such a manner as not to expose another person to infection"; undergo a medical examination; and submit to necessary treatment. ${ }^{35}$ The medical health officer may issue such an order if she or he has reasonable and probable grounds to believe three conditions exist: (1) "a communicable disease exists or may exist or that there is an immediate risk of an outbreak of a communicable disease"; (2) "the communicable disease presents a risk to the

Health Canada, News Release. "Questions and Answers - Updated Quaramine ACI" (2004), online: <www.hc-sc.ge.ca/english/media/releases/2004/2004_23bk I.htm> [Health Canada News Release. 2004]. In Third Reading debale in the Housc of Commons, the Minister of State for Public tlealth empliasized key features of the Bill:

The modernized act we have proposed has a new focus on airline travel and will provide the Minister of Health with additional authority. For example, Bill C-12 would enable the minister: to divert aircraft to an alternate landing site if necessary to isolate and contain a public health threat: to establish quarantine facilities at any location in Canada; [and] to order a carrier to not enter Canada if there are serious concerns that the arrival may threaten the public health of Canadians.

See House of Commons Debates. 054 (10 February 2005) at 11:55 (Hon. Carolyn Bennett), online: <www.parl.gc.ca/38///parlbus/chambus/house/debates/054_2005-02-10/han054_I155-E htm\#lnt$1120295>$. In addition to the diseases listed under the current Quarantine Act, the new legislation also include: diseases such as active pulmonary tuberculosis. anthrax. diphtheria. measles and poliomyelitis. Health Canada News Releasc, 2004, supra note 30.

" House of Commons Debates, 055 (14 May 2004) at 12:50 (Hon. Carolyn Bennett), online: <www.parl.gc.ca/37/3/parlbus/chambus/house/debates/055_2004-05-14/han055_1250-E.htm>. Supra note 6.1 focus here on Ontario's legislation as its adequacy was tested during the SARS outbreak. Ibid., s. 22(4). 
health of persons"; and (3) "the requirements specified in the order are necessary in order to decrease or eliminate the risk to health presented by the communicable disease." ${ }^{36}$

Although the language in Ontario's public health statute is relatively broad, public health officials encountered at least one gap in the law that stymied their use of quarantine powers: the statute only provided for orders directed to individuals. To remedy this shortcoming, the Health Protection and Promotion $\mathrm{Act}$ was amended during the 2003 SARS outbreak to specify that an order may be directed at an individual or a class of persons. ${ }^{37}$ This amendment was critical to enable public health officials to deal with situations involving hundreds or thousands of people who may have been exposed to an infectious disease, such as nearly 2000 high school students. The statutory amendment stipulates that notice may be communicated through the media or other public mechanism when the delay involved in notifying persons individually is "likely to cause a delay that could, in the opinion of the medical officer of health, significantly increase the risk to the health of any person." 38

Under Ontario's statute, a medical health officer must inform individuals subject to a quarantine order of their right to a hearing before the Health Services Appeal and Review Board, an administrative tribunal composed of 12 members appointed by government. ${ }^{39}$ The individual must request a hearing in writing within 15 days of receiving notice of an order. In turn, the Board is obliged to hold a hearing within 15 days of receiving a hearing request and has authority to uphold, vary or rescind the order..$^{+0}$

While Ontario's public health statute was amended during the SARS outbreak, the government later introduced a new emergency management statute. ${ }^{\text {" }}$ Among other things, this Bill amends the definition of "emergency" to explicitly include dangers posed by disease or other health risks. ${ }^{2}$ The proposed legislation also specifies types of orders the Lieutenant Governor in Council may make during an emergency, including the power to regulate and prohibit travel, evacuate individuals, close premises and procure goods needed to respond to the outbreak. The Bill also strengthens penalties for failing to comply with those orders. An individual may face a fine of up to $\$ 100,000$ and imprisonment for up to one year and a corporation may be fined up to $\$ 10$ million. ${ }^{43}$

If. Ibid., s. 22(2).

"l) bid., s. 22(5.0.1), amended, 2003, c. I, s. IS(1)

3* Ibid., s. 22(5.0.3).

" Ministry of Health Appeal and Review Boards Act. S.O. 1998, c. 18.

41 Supra note 34, s, 44.

"I See Bill 138, Emergency Management Siamme Law Imendmemt Act, Ist Sess., 38th I.cg.. Ontario, 2004 (as passed at First Reading on 10 November 2004).

12 The existing Emergency' Managemen Acr defines emergency as "a situation or an impending situation caused by the forces of nature. an accident, an intentional nct or otherwise that constitutes a danger of major proportions to life or property." Eimergency Managemen ACt, R.S.O. 1990, c. E-9, s. I. imposed on the person by an amount equal to the financial benefit that was acquired by or that amount accrued to the person as a result of the commission of the offence." Sec also s. 7.0.12(3). 


\section{Legislative Gaps and Operational. Deficiencies}

Despite efforts to identify and address gaps in public health laws, some legislative shortcomings remain in regard to the use of quarantine. For instance, though individuals typically have a right to appeal a quarantine order, this protection may be illusory in many cases. A person may be ordered to observe quarantine for a period of ten or 15 days from the date of the notice. Under Ontario's legislation the order takes effect immediately, even if the person subject to the order evinces an intention to appeal the order. ${ }^{44}$ After the Health Services Appeal and Review Board receives the notice of hearing, the Board has discretion to suspend the quarantine order, but is not bound to do so. By the time the Board hears the appeal, the matter may well be moot since the quarantine period will likely have passed. Ottawa's new quarantine legislation addresses this issue at the federal level by requiring review of a quarantine detention within 48 hours of request."

At present, Ontario's legislation and the federal Quarantine Act are silent with regard to obligations to assure acceptable detention conditions for persons under quarantine outside their homes. ${ }^{46}$ Model emergency health powers legislation developed by public health legal expers in the United States provides a template for legislative authority during an event such as an infectious disease outbreak. ${ }^{47}$ This legislation explicitly addresses responsibilities of public health officials toward individuals who must comply with mandatory quarantine orders. For example, if an individual must wait out the quarantine period in a location other than her or his home, authorities must ensure those premises are safe and hygienic and provide individuals with necessities such as food, clothing, medication and means to communicate with the outside world. In addition, the model U.S. legislation provides for expedited judicial review of quarantine orders and entitles individuals to legal representation. Such legislative protections advance principles of fairness, due process and respect for persons.

It is important to recognize that public health legal preparedness is not achieved solely by enacting new laws or modernizing old ones. Moulton and colleagues observe:

At first glance. public health legal preparedness may appear to be only a maticr of having the right laws on the books. On closer examination. however, it is as complex as the field of public health practice itself. Public health legal preparedness has at least four core elements: laws (statutes, ordinances, regulations, and implementing measures); the compelencies of those who make, implement, and interpret the laws: information critical to those multidisciplinary practitioners; and coordination across sectors and jurisdictions. ${ }^{48}$

The Canadian experience with SARS underscores these points. The outbreak compelled legislators to re-examine public health laws in a twenty-first century context of novel diseases and jet-speed global travel. However, legislative reform, while necessary. is not sufficient on

Supra note 34. s. 44(3).

Supra note 29, s. 29.

However. it is impontant to note that the new federal quarantine legislation authorizes the making of regulations "respecting the specifications" for quarantine lacilities (ibid. s. 62).

Lawrence O. Gostin, et al.. "The Model State Emergency Health Powers Act: Planning for and Response to Biotertorism and Naturally Occurring Infectious Diseases" (2002) 288 JAMA 622.

Supra note 2 at 681. 
its own to ensure adequate public health preparedness. This point is demonstrated by various criticisms directed at the adequacy and effectiveness of the Canadian federal response at airports. First, in 2002, the year prior to the SARS outbreak, the federal government transferred airport quarantine duties to customs officials with no special training to carry out those responsibilities. ${ }^{49}$ When the SARS outbreak occurred, "quarantine officers were quickly overextended and eventually needed additional assistance" 50 to carry out their duties. Additionally, early in the outbreak, before the cause of SARS was known, federal health officials could not provide definitive decontamination protocols for aircraft, cruise ships or other conveyances.

In the wake of the SARS experience, the Naylor Report recommended the federal government ought to ensure "[f]ully trained and informed quarantine officers should be available at airports [and other ports of entry] to deal with health threats, to provide information to and educate airport staff, customs officials and airline personnel concerning the recognition of illness and measures to be taken to contain risk."si A modernized quarantine statute is of no use without adequately trained persons with the resources to apply it.

\section{THE IMPACTS OF QUARANTINE}

The harsh toll SARS exacted, including the many detrimental impacts of quarantine, came to be termed the "collateral damage" of the outbreak. 52 In this section, I highlight some of the consequences of quarantine, both for health care workers and others. Laura Hawryluck and colleagues emphasize that "[k]nowledge and understanding of the experiences of quarantined persons are critical to maximize infectious disease containment and minimize the negative effects on those quarantined, their families, and social networks."\$3

It has been noted that "the SARS outbreak is unique in recent history in its rapidity of transmission, its concentration in health care settings and the large number of health care workers who have been infected." $\$ 4$ In fact, health care workers accounted for over 40 percent of SARS cases in the Toronto area and a key challenge was "to manage and allocate health care staff as the illness forced the quarantine of dozens of SARS-exposed workers." "5s

Recent studies have assessed the impact of quarantine (and other measures associated with control of SARS) on health care workers and others. ${ }^{56}$ In general, the unsurprising conclusion

4. Naylor Report, supra note 5 at 205.

so Ibid.

s1 Jbid. at 207

s2 Mark Bernstein, "SARS and Ethics" (2003) 7:I Hospital Quarterly 38.

31 Supra note 18 at 1206.

st Robert Maunder ef al. "The inmmediate psychological and occupational impact of the 2003 SARS outbreak in a teaching hospital" (2003) 168 Canadian Medical Association Journal 1245 at 1245.

"s Brad Mackay, "SARS: 'a domino effect through entire system"" (2003) 168 Canadian Medical Association Journal 1308 at 1308.

*. Sec e.g. Leslie A. Nickell et al., "Psychosocial eftects of SARS on hospital staff: survey of a large tertiary care institution" (2004) 170 Canadian Medical Association Journal 793; Maunder et al., supro note 54; and Robert Maunder. "The experience of the 2003 SARS outbreak as a traumatic stress among frontline healthcare workers in Toronto: lessons learned" (2004) 359 Philosophical Transactions of the 
is that "[t]he effect of SARS on the health care system in the greater Toronto area was dramatic ... the SARS outbreak had significant psychosocial effects on hospital staff... The effects on families and lifestyle was also substantial." "Further, the Naylor Report cautions that "[t]he impact of SARS on individuals working within the health system should not be underestimated." $\$ 8$

In regard to the specific impact of quarantine, an editorial in a Canadian nursing journal comments:

The procedure of quarantine, from its beginnings, seems to have been imposed from the outside, as a law or interdict, and resulted in, or at the very least represented, segregation, social and psychological isolation. stigma, reduced social status, and the potential powerlessness of those affected. ${ }^{59}$

One nurse expresses her views as follows: "I am ordered into quarantine and feel as though such a restriction could apply only to some plague-threatened inhabitant of the Middle Ages."

Health care workers in quarantine reported feeling disconnected and at a disadvantage when they returned to work because they were not up to date on key information, including the latest infection control protocols. This reaction demonstrates the need for ongoing communication with workers who are in quarantine so that if they do not become ill, they can return to work feeling ready to do so. ${ }^{61}$ Physicians in quarantine who were interviewed at the height of the outbreak "described anxiety about the wellbeing of ill colleagues and their frustration in not being able to elicit details about their condition." 62 While patient confidentiality must be respected, health care facilities ought to be aware that "[f]or those quarantined, knowledge of how their colleagues were faring may have alleviated some of their stress." ${ }^{+63}$

Royal Society of London B III7 [Maunder. "Lessons Learned"].

Nickell et al., ibid. at 793.

Supra note 5 at 155.

Francine Wynn \& Elizabeth Peter, "Nurses and Quarantine: Reflections upon the SARS Crisis in Toronto" (2003) 10 Nursing Inquiry 207 at 207.

(r11 Karen Ellacott, "Behind the mask" (2003) I5 Registered Nurses Journal 12 at 14.

4t A report of one Toronto hospital's experience with ntaintaining communication with health care workers in quarantine comments:

[A] number of our staff were put on home isolation after having unprotected exposure to a patient in our Intensive Care Unit... Suddenly we were faced with a whole new challenge - how to communicate with large numbers of staff at home... The hospital's intormatics stafi quickly established a "lifeline" for staff by providing access to their lospital email from home and crealled a password-protected SARS Internet site through our website. This enabled stafr to stay on tup of what was happening at the hospital during their absence and reduced their reliance on the media for intormation.

Sec Fran McBride. "Communicating During a Crisis -- The SARS Story at Mount Sinai Ifospital" (2003) 6:4 Hospital Quantrly 51 at 52.

«: Sharon E. Straus et al. "Severe acute respiratory syndrome and its impact on prolessionalism qualitative study of physicians" behaviour during an emerging healtheare crosis" (2004) 324 l3nilush Medical Journal 83. 
In addition to psychosocial impacts on health care workers, quarantine and other measures used to control the spread of SARS had major consequences on access to health care. The provincial "Code Orange" directive that required Ontario hospitals to restrict access to all but the most critically ill patients meant that a vast number of services, including surgeries and other procedures such as radiation therapy for cancer patients, were cancelled. ${ }^{64}$ The quarantine of health care workers exacerbated this already difficult situation. The Naylor Report estimates the cost of addressing the surgical backlog at $\$ 32.1$ million. ${ }^{\circ 5}$ In addition, family and friends of patients in hospital were either not allowed to visit or access for visitors was severely restricted.

When hospital services began returning to normal, surgeries that had been cancelled had to be rescheduled. One contentious point is that "patients were often allocated to operating rooms not based on urgency of their condition but based on an equitable distribution of finite operating resources within different surgical divisions (e.g., orthopedics, neurosurgery, plastic surgery, and so on). Many felt this was not fair or appropriate resource allocation."

Overall, "[i]n the public perception, the SARS outbreak turned the modern world of healthcare on its head in Toronto, in the sense that healthcare workers were seen as victims and vectors of disease rather than healers, and hospitals were seen as contaminated areas rather than places fostering health."67

While quarantine during SARS had a unique impact on workers and patients within the health care system, it also disrupted the lives of ordinary citizens who faced over a week of segregation because they had the misfortune of possible exposure to SARS. Studies have focused on assessing the effect of quarantine on health care workers, but some research has attempted to explore the experiences of others who observed quarantine. The findings of one Toronto survey are not unexpected:

All respondents described a sense of isolation. The mandated lack of social and, especially, the lack of any physical contact with family members were identified as particularly difficult. Confinement within the home or between work and home, not being able to see friends, not being able to shop for basic necessities of everyday life ... enhanced their feeling of distance from the outside world. ${ }^{68}$

In addition to its impact in the health care system, quarantine had significant economic consequences. Thousands of employees lost income while they stayed home to observe quarantine or provide care for others who were quarantined. It has been argued that the ethical value of reciprocity demands that the state compensate those whom it asks to stay home from work to comply with quarantine. ${ }^{69}$ Expressed in practical terms:

Bernstein, supra note 52. For detailed analysis of the impact of SARS on hospital activities, including visits to emergency departments and surgery volumes and backlogs, see Naylor Report, supra note 5 al 155.60. 
[A] person potentially missing a mortgage or car payment may face a strong temptation to break quarantine in order not to lose earnings. By promising compensation, the government creates incentives to stay home, and thereby limits the risk that SARS may spread, thus reducing the economic dislocation caused by the discase. ${ }^{70}$

Some people had to use vacation time or take unpaid leave in order to observe quarantine. It has been observed that "the initial refusal of governments to recognize the lack of an income cushion for Torontonians obeying quarantine orders clearly contributed to reluctance of some to stay away from work, further spreading SARS." "This view is echoed by legal counsel for the City of Toronto who was involved in drafting mandatory quarantine orders when individuals failed to accede to voluntary requests:

People were cooperative, but among other things, the voluntary isolation presented financial hardships for families with one income earner who was suddenly placed under home isolation. The situation became extraosdinarily difficult, and public health authorities found that a few circumstances required legal intervention. $^{72}$

The government of Ontario enacted new legislation, the SARS Assistance and Recovery Strategy Act $2003,{ }^{73}$ to give job protection to employees who were observing quarantine or had to stay home from work to care for another individual, such as a child, who was quarantined. This law, which came into force on 5 May 2003, had retroactive effect to 26 March 2003, to authorize unpaid leaves of absence for employees in various circumstances, including those observing quarantine or receiving treatment for SARS. A SARS Assistance Plan was also announced to offer some financial compensation to people who lost income during periods of quarantine.

\section{Legal Challenges to Quarantine Orders}

Quarantine orders may be challenged on various legal grounds, but I focus briefly here on constitutional challenges under the Canadian Charter of Rights and Freedoms, ${ }^{74}$ which guarantees a number of fundamental rights with which the state cannot unjustifiably interfere. Quarantine orders may infringe on various rights protected under the Charter, including the freedom of assembly and association (s. 2), mobility rights (s. 6), rights to liberty and personal security (s. 7), freedom from arbitrary detention (s. 9), freedom from cruel and unusual treatment (s. 9), and equality rights (s. 15).

The most likely constitutional basis for challenging a quarantine order is $\mathbf{s} 7$ of the Charter, which states: "Everyone has the right to life, liberty and security of the person and the right not to be deprived thereof except in accordance with the principles of fundamental

7) Edward lacobucci, "Do SARS bailouts make sense?" National Posi (3 May 2003) A24.

" Canadian Public Health Association, "Public Health in the Public Intcrest: A Contribution from the Canadian Public Health Association to the National Advisory Conmittce on SARS and Puhlic Health" (2003), online: <www.cpha.ca/english/sars/brief_e.pdP- at 12.

12 Jane Speakman, Fernando González-Martin \& Tony Perez. "Quarantine in Severe Acure Respiralors Syndrome (SARS) and Other Emerging Infectious Distases" (2003) 31 J.1. Med \& lithics (Special Supp.) 63 at 63 .

n S.0. 2003, c. 1.

14 Conadian Charter of Rights and Freedoms, Pan I of the Constitution .1ct. 1982. being Schedule I3 II the Canada ACl 1982 (U.K.), 1982, c. II [Charser]. 
justice." ${ }^{35}$ Section 7 protects against unreasonable, state-imposed restraints on liberty as well as government action that imposes severe psychological stress. ${ }^{76}$

Charter rights are not absolute and infringements may be justified under $\mathrm{s}$. I of the Charter, which states: "The Canadian Charter of Rights and Freedoms guarantees the rights and freedoms set out in it subject only to such reasonable limits prescribed by law as can be demonstrably justified in a free and democratic society."

Under s. 1, the state may justify a Charter violation by convincing a court that: first, its action was based on a pressing and substantial concern; second, its goal was rationally connected to the limitation imposed on an individual's rights; third, the limitation impairs the individual right in a minimal fashion; and lastly, there is proportionality between the benefits of the limitation and its harmful impact. ${ }^{78}$ Gostin cautions that "[i]]n a democratic society ... coercive [public health] powers should be carefully justified. We have to balance the public health interests of society against the freedom of the individual."”9

The key challenge under s. 1 is to balance the rights of individuals with the competing interests of society as expressed through government action. A former Chief Justice of the Supreme Court of Canada has advised that "[i]t may become necessary to limit rights and freedoms in circumstances where their exercise would be inimical to the realization of collective goals of fundamental importance." ${ }^{80}$ The Supreme Court of Canada has further instructed that in justifying a limitation on a Charter right, the government need not provide "scientific demonstration"; rather, it can defend its actions "by the application of common sense to what is known, even though what is known may be deficient from a scientific point of view." disease outbreak, public health authorities will often lack scientific facts and must make judgment calls about restricting individual liberties in the name of protecting the population as a whole.

Despite this general guidance as to how Charter infringements may be justified, there is little Canadian jurisprudence that directly addresses potential constitutional violations in the public health context. Consequently, Canada does not have a corpus of legal rulings that instructs how to apply specific Charter rights and the $s .1$ justification test in regard to public health interventions. This contrasts with the U.S. where courts have given specific instruction as to how to balance competing interests at stake in public health. For example, it has been noted that "[t]he judge must defer to public health authorities on their choice of public health strategies. Public health orders get the most permissive judicial review ... because they are

Ibid., s. 7.

" Blencoe v. British Columbia (Ihuman Righis (ommission). [2000] 2 S.C.R. 307. 2000 SCC 44: Niw. Brunsurick v. J.G., [1999] 3 S.C.R. 46.

"Charter, supra note 74, s. 1 .

7* R. v. Oakes, [1986] I S.C.R. 103 [Oakes].

7) Lawrence O. Gostin, ed. Public Healih Lan and Eihics: A Reader (Berkeley: Universily of California Press, 2002) at 415-16.

Oakes, supra note 78 at 136

"1 RJR-MacDonald Inc. v. Canada (Altorney General), [1995] 3 S.C.R. 199 at para. 137. 
based on objective critieria, are usually of limited duration, and are necessary to prevent imminent harm."

In two cases where courts have balanced claims of individual Charter rights against a broader public health interest, the latter has prevailed. The 1995 Ontario court decision in Canadian AIDS Sociery $v$. Onfario ${ }^{83}$ involved HIV testing of stored blood that had been donated some 11 years previously. When the blood was collected from the donors between 1984 and 1985, they were not advised the blood would be tested for HIV as no such testing capacity existed at that time. When testing became available, the Canadian Red Cross Society tested the stored samples to trace any recipients of contaminated blood. Twenty-two HIVpositive donors were identified, nine of whom had previously been identified, leaving 13 remaining donors. The issue that arose in this case was whether the Red Cross should notify the donors and report them to the Province of Ontario in accordance with the Health Protection and Promotion Act. ${ }^{84}$ The Canadian AIDS Society objected to donor notification and reporting on the basis that the donors had not consented to testing their blood for HIV and notification and reporting would violate the donors' privacy rights.

The Court accepted that s. 7 of the Charter may be interpreted to recognize a blood donor's privacy interest in regard to personal information revealed through testing their blood samples. However, the Court went on to rule that the public interest in mandatory reporting of HIV cases to public health authorities outweighed the individual donors' privacy interests. The Court noted that "although due consideration will be given to the privacy rights of individuals, the state objective of promoting public health for the safety of all will be given great weight."

In 2002, a court in Ontario applied similar logic in adjudicating a Charter challenge by a tuberculosis patient who was under detention for treatment. ${ }^{86}$ The patient had agreed to a four-month detention and treatment order by the medical health officer but challenged a further four-month extension order, which health professionals believed was necessary to control his disease. The patient had been physically restrained on occasion to prevent escape $^{87}$ and he argued the restraints and continued detention violated his constitutional liberty rights. In a brief judgement, the Court accepted his rights were violated, but concluded the infringement was justified under s. 1 of the Charter. The Court stated:

What was done to [the patient] was carried out lor the protection of public health and the prevention of the spread of tuberculosis, a disease that [a medical specialist] described as cxtremely contagious. [The patient] is in the early stages of the disease, it is eminently treatable now. but will become less responsive and more virulent if not treated. ${ }^{88}$

Edward P. Richards \& Katharine C. Rathbun, "Making Stale Public Health Laws Work for SARS Outbreaks" (2004) 10:2 Emerging Infectious Diseases 356 [foolnotes omitted]. Sec also Lawrence $O$ Gostin, Public Health Law: Power, Duty, Restraint (Berkeley: University of California Press. 2000). (1995), 25 O.R. (3d) 388 (Gen. Div.).

Supra note 6.

Ibid. at para. 133

Toronto (Cin. Medical Officer of Healhh) y. Deakin. [2002] O.J. No. 2777 (Cl. J.) (QL).

Jbid. at para. 26. The patient absconded from the treatment centre on one occasion to purchase beer and had been restrained during several violent outbursts.

Jbid. 
Despite the dearth of Canadian constitutional jurisprudence in the public health context, it appears courts will recognize the need to balance competing interests and will likely give deference to public health officials who must act during times of uncertainty and possible emergency. Only in situations involving abitrary or unreasonable exercise of public health powers are courts likely to find a breach of rights protected under the Charter. Yet, when might quarantine be considered unjustifiable?

In the specific context of large-scale quarantine, Joseph Barbera and colleagues argue public health authorities should address three key questions before choosing to use quarantine. ${ }^{89}$ First, does medical evidence indicate that quarantine is likely to be effective in limiting the spread of disease? Second, from a logistical perspective, can officials safely and effectively quarantine large numbers of people? Third, do the potential benefits of quarantine outweigh its adverse impacts?

It is arguable that the wide-scale imposition of quarantine during the SARS outbreak in Canada, albeit mostly voluntary, was used excessively and, in some cases, would fail to pass the threshold question of being an effective measure to diminish disease transmission. Beijing and Toronto both quarantined around 30,000 people, but Beijing had ten times as many SARS cases as Toronto: 2,500 compared to Toronto's 250 . The U.S. Centers for Disease Control and Prevention has suggested "that only a third of the 30,000 Beijing residents quarantined during the SARS outbreak faced significant risk of contracting [the disease because] only residents who came into direct contact with a symptomatic patient were later infected; those who cared for a SARS patient carried the highest risk.,"10 If Beijing used quarantine too often, then Toronto's greater use is perhaps even more suspect.

It may also be contended that quarantine on this scale was unenforceable; indeed, research describes the inability of public health officials to contact individuals in a timely manner to advise them to observe quarantine. In Toronto, the Department of Public Health identified over 23,000 persons who were contacts of SARS patients and, arguably, ought to have been quarantined. ${ }^{.1}$ Of these, approximately 9,000 could not be reached at all by public health officials or only after the ten-day quarantine period had expired.

Finally, evidence indicates that people with SARS are most infectious five to ten days after developing symptoms ${ }^{22}$ and there are no documented cases of an asymptomatic individual transmitting the disease to another. ${ }^{93}$ This knowledge suggests that quarantining people who have no symptoms will be of linle utility. As a consequence, resources ought to be directed at segregating and caring for persons with symptoms and at public education strategies to (2001) 286 JAMA 2711

Bruce Diamond, "SARS spreads new outlook on quarantine inodels" (2003) 9 Nature Medicine 1441. citing Centers for Disease Control and Prevention, "Efliciency of Quarantine During an Epidemic of Severe Acute Respiratory Syndrome - Beijing, China, 2003" (2003) 52 Morbidity \& Mortality Weekly Report 1037.

"Svoboda, supra note 7.

"2: I.S.M. Peiris er al., "Clinical progression and viral load in a conumunity outbreak of coronavirusassociated SARS pneumonia: a prospective study" (2003) 36 I The Lancet 1767.

$+1$ Thomas G. Ksiazek ef al., "A Novel Coronavirus Associated with Severe Acute Respiratory Syndrome" (2003) 348 New England Journal of Medicine 1953. 
ensure people can recognize symptoms of the disease and know when to seek medical attention.

\section{Conclusion}

The $\mathbf{2 0 0 3}$ global outbreak of SARS forced public health systems worldwide to evaluate their capacity to respond to a novel disease crisis. As with other countries hit hard by the outbreak, quarantine was heavily used as a public health intervention to attempt to control the disease in Toronto. Ontarians were extremely compliant in voluntarily accepting a temporary restriction on their liberty for the broader benefit of their communities. However, public health officials cannot always assume individuals will not resist coercive restrictions. Anderson and colleagues give the following caution:

[l]t is difficult to escape the conclusion that the world community was very lucky this time round, given the very low transmissibility of the agent, plus the fact that fairly draconian public health measures could be put in place with greal efficiency in Asian regions where the epidemic originated. Given the litigious nature of people in North America in particular, and to a lesser degrec in western Europe, the control of SSEs [superspreading events] in these regions might have presented greater problems if mass quarantining had been required. 94

A representative of the American Civil Liberties Union echoes this concern, though points out that "North American litigiousness" is far more characteristic of the U.S. than Canada: "I think Americans will be more skeptical about quarantine proposals than Canadians are, and probably more anxious to exercise their legal rights."

It is arguable that quarantine was overused during the SARS outbreak and, in many cases, was likely not a truly effective measure in reducing disease spread. Commentators have suggested that "[i]n hindsight, overrecognition of contacts, especially in two hospitalwide quarantine efforts, may have resulted in an overestimate of the number of persons requiring quarantine." 96 Yet, the phrase "in hindsight" is significant and public health officials clearly must have some degree of latitude when responding to a novel disease outbreak. Interventions that are based on up-to-date evidence and that are not applied in an arbitrary, unfair or discriminatory manner are most likely to pass legal scrutiny.

Various examples from Toronto's experience with SARS demonstrate that public health officials were concerned with applying quarantine fairly. For instance, although the outbreak had a major economic impact on businesses in Toronto's Chinatown, quarantine was not applied in discriminatory manner against Chinese Canadians. Historical practices of quarantine based on racial prejudices were not repeated. As well, public health officials strove to apply evidence-based quarantine. Despite the retrospective observation that quarantine may have been implemented too broadly, officials resisted "pressure to lengthen 
the quarantine period to 14 days [because] data did not support a quarantine period longer than 10 days." 97

After successfully containing SARS, public health authorities and legislators have focused attention on the need to renew and modernize public health legislation. Gene Matthews and colleagues observe that "[l]aw is an essential tool for public health. Law sets the structure within which public health officials, regulators, and private citizens act to protect the population's health. Law can impede that process ... or it can enhance it." ${ }^{.98}$ While laws are "only one tool in Canada's public health toolbox," the crucial role of law in public health is highlighted by the national and provincial commissions of inquiry that have analyzed the Canadian SARS outbreak and recommended strategies to equip the public health system for the next outbreak. ${ }^{100}$

A key initiative underway in Canada is the development of a national Public Health Agency to be tasked with responsibilities related to infectious and chronic diseases and emergency planning and response. ${ }^{101}$ Canada's first Chief Public Health Officer was appointed in late September $2004 .^{102}$ This Agency has potential to serve a key role in enhancing national readiness and coordinating future outbreak response. Indeed, it has been noted that "[a]t least one positive development might emerge from Canada's recent outbreak of [SARS]: the creation of a national disease control centre similar to the Centers for Disease Control and Prevention (CDC) in the US." ${ }^{103}$ However, as provinces have primary constitutional authority over health, a federal agency will face legal limits on its ability to act unilaterally and will likely strive to collaborate, rather than dictate.

Needed efforts to renew and modernize public health laws are underway in Canada, with the federal government introducing an updated quarantine statute and continuing its work toward enacting comprehensive health protection legislation to replace existing laws goveming food, drugs and hazardous products. Various provincial governments are also reviewing their public health laws. The SARS experience taught officials that legislation

Ibid.

Gene W. Matthews, et al., "Legal Preparedness for Bioterrorism" (2002) 30 J.L Med. \& Ethics 52 at 53.

House of Commons Debures, 054 (10 February 2005) at 11:55 (Ilon. Carolyn Bennett), online:

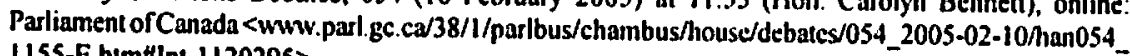
1155-E.htm\#lnt-1120295>.

In addition to the Naylor Report, supra note 5, see also Ontario SARS Conmission. Imterim Report on SARS and Public Health in Ontario (Ontario: Ministry of Health, 2004), online: < www.health.gov.on. ca/english/public/pub/ministry_reports/campbell04/campbell04.pdf $\$$; Senate Standing Committee on Social Affairs. Science \& Technology, Reforming Health Prolection and Promotion in Canada: Time 10 Act(Ottawa: Senate, 2003), online: < www.parl.gc.ca/37/2/parlbus/commbus/senate/com-e/soci-e/repe/repfinnov03-e.htm>: Ontario, For the Public's Health: A Plan of Action - Final Report of the Oniario Expert Panel on SARS and infectious Disease Control (Ontario: Ministry of Health, 2004). online: <www.health.gov.on ca/english/public/pub/minislry_reports/walker04/walker04_mn. html>. Public Health Agency Backgrounder, The Public Healih Agency of Canado (Canada: Health Agency of Canada, 2004), online: <www. phac-aspc.gc.ca/about_apropos/index.html>

Public Health Agency News Release, "Government of Canada Appoints First Chief Public Ileallh Officer to Head Public Health Agency of Canada" (Ottawa: Health Agency of Canada, 2004), online <www phac-aspc.gc.ca/media/nr-rp/2004/phac_nr_e.htmls.

Sieve Wharry. "Will SARS crisis give Canada its own CDC?" (2003) 168 Canadian Medical Assuciation Journal 1581. 
authorizing public health interventions like screening, isolation, quarantine and treatment must be sufficiently flexible to allow rapid response to a new infectious agent. For example, many public health statutes have schedules listing various infectious diseases for which coercive interventions are warranted. Such lists must be capable of swift amendment so officials are not hamstrung in their ability to respond to a disease outbreak because a novel agent is not yet covered by public health legislation. Similarly, the SARS experience reveals that officials ought to have the legal authority to implement class quarantine orders as it may be unworkable to issue individual orders to thousands of people. The mandated length of quarantine must be based on the best available evidence to ensure individual liberty is not restricted any longer than necessary.

Government officials who impose restrictive measures like quarantine should concurrently offer resources to mitigate individual hardships. Workers who cannot report to work because they are in quarantine face, at a minimum, income interruption and at worst, job loss. Legal mechanisms may be necessary to protect employees' jobs and compensate them for lost income during periods of quarantine. If the next disease is more virulent than SARS then public health officials cannot afford the consequences of individuals breaking quarantine to go to work so they can buy groceries for their families.

Looking back on SARS, it is worthwhile to keep in mind the following caution: "In the next global epidemic ... we may not be so lucky.... Thus one of the major dangers arising from the effective control of SARS is complacency. Sentiments of the type "we have been successful once - we will be again' may be far from the truth." ${ }^{104}$ Clearly, public health authorities at local, national and international levels must remain vigilant to respond to the next, novel infectious agent when - not if - it happens again. Ensuring appropriate public health legal preparedness is one key aspect of maintaining that vigilance. 